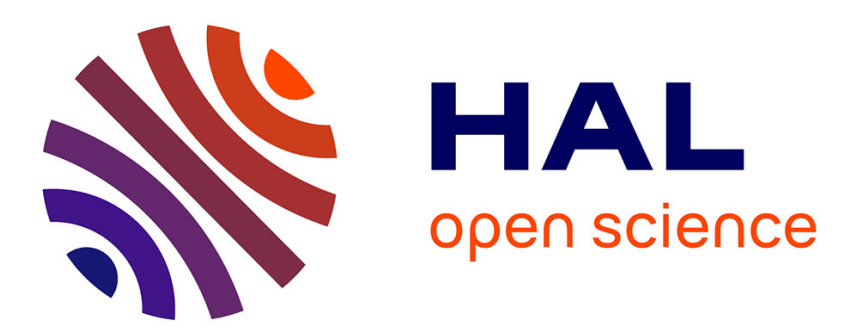

\title{
Dissemination of knowledge and copyright: an historical case study
}

\author{
Tony Volpe, Joachim Schöpfel
}

\section{To cite this version:}

Tony Volpe, Joachim Schöpfel. Dissemination of knowledge and copyright: an historical case study. Journal of Information, Communication and Ethics in Society, 2013, 11 (3), pp.144 - 155. 10.1108/JICES-06-2013-0018. sic_01088896

\section{HAL Id: sic_01088896 \\ https://archivesic.ccsd.cnrs.fr/sic_01088896}

Submitted on 28 Nov 2014

HAL is a multi-disciplinary open access archive for the deposit and dissemination of scientific research documents, whether they are published or not. The documents may come from teaching and research institutions in France or abroad, or from public or private research centers.
L'archive ouverte pluridisciplinaire HAL, est destinée au dépôt et à la diffusion de documents scientifiques de niveau recherche, publiés ou non, émanant des établissements d'enseignement et de recherche français ou étrangers, des laboratoires publics ou privés. 


\title{
Dissemination of Knowledge and Copyright. A Historical Case Study
}

\author{
Tony Volpe \& Joachim Schöpfel
}

\section{Introduction}

Registration, certification, dissemination, and archiving: since the conception of Oldenburg's Philosophical Transactions, publishers and authors share a common set of convictions on the main functions of a scientific journal.

A scientific journal should act as a public register of intellectual property, brand (or label) articles and create visibility, serve the transmission of scientific information, and help keeping a record of science (Guédon, 2001, pp. 15-18).

Of course, other features contribute to academic publishing, especially psychological drivers and human factors such as "ego, vanity, recognition, reward and immortality" (Mabe, 2009, p. 3), social and societal aspects, politics, and strategic considerations (Roosendaal et al., 2010, p. 19-36). Evaluation becomes a core function of scientific journal publishing.

Yet, the basic concept of a scientific journal remains unchanged. "The four functions of Oldenburg's journal (...) are so fundamental to the way scientists behave and how science is carried out that all subsequent journals, even those published electronically in the $21 \mathrm{st}$ century, have conformed to Oldenburg's model" (Mabe, 2009, p. 5).

These core functions of scientific communication do not necessarily co-exist in harmony. It occurred only later that there might be conflict between these functions, in particular between registration, i.e. protection of author's rights, and broad dissemination of knowledge. Today, Internet and the open access movement challenge their importance, rank and correlation. Prevailing immediate and direct communication (dissemination) may raise quality issues (certification) and impact permanent recording. In the current crisis of copyright, this is matter of debate with regards to scientific communication via blogs, social networks, wikis, personal websites and open repositories (see for instance the proceedings in Gaster, Schweighofer and Sint, 2008).

Copyright, which means the protection of intellectual property and economic interests of publishers, authors and printers and its relationship to the creation and publication of scholarly works, is "a critical concern for the advancement of new knowledge" (Crews and van Westrienen, 2007, n.p.). Does copyright stimulate artistic and scientific creation? Does it facilitate dissemination of information and culture?

In 2010, a German economic historian roused a passionate debate about intellectual property laws, technological innovation and economic growth. Eckhard Höffner's research on 19th century Germany suggests that a weak copyright system due to political fragmentation may have incited economic growth by making technical manuals and other practical books cheap and easily available, helping Germany catch up with Britain (Höffner, 2010).

So, does copyright protection reduce intellectual and industrial creation? Höffner's thesis was followed by an international and controversial debate in papers, blogs and wikis. 
Dobusch (2011) for instance argued that "according to Höffner, this much broader availability of specialist and technical literature was then responsible for Germany's industrial catchingup in the $19^{\text {th }}$ century" (p. 22) and concluded that "a vibrant public domain (is) relevant for economic and societal development" (p. 33). Others, as the judge and senior lecturer at the University of Chicago Law School Richard A. Posner relativized the impact of copyright, especially when compared to patent law protection (Posner, 2012), or they stressed the role of intellectual property protection for innovation, such as a contribution from the leading Chinese business school CKSGB at Beijing (Voyles, 2013). The only shared conviction was that a complex topic needs complex answers.

Our intention is to provide more controversial evidence to this debate based on a case study from history of science. In our case, Denys de Sallo's Journal des Savants considered as the world's oldest scholarly journal still active today (Potts, 2011, pp. 68-69) with private rather than corporate character (Cook, 2001, p. 16) opposes Elzevier (also spelled Elzevir or Elsevier), a Dutch family of publishers, booksellers and printers of the $17^{\text {th }}$ and $18^{\text {th }}$ centuries (no link with the modern publishing house of the same name).

Our story is that Elzevier, through non authorized exploitation of a new product and without considering the editor's legitimate interests in a context of the absence of copyright protection, largely contributed to the dissemination of the French Journal des Savants and its content, and finally to the success of scientific journals.

The story may appear old, from the past and sometimes a little bit hard to understand. Yet, the underlying questions and the search for solutions are still relevant today.

\section{The Republic of Letters, community and communication}

Beyond social barriers and political, religious or linguistic frontiers, intellectuals of the second half of the seventeenth century often saw themselves as belonging to a Republic of Letters, characterized by the search for truth and open communication among its members. The expression "Republic of Letters" designated the community of scientists and scholars who cultivated knowledge. Moreover, all those who adhered to the ideals of this great intellectual community had a duty to transmit, communicate and disseminate knowledge. They were fully aware that intellectual progress required the development of communication. Communication was at the heart of the concerns of the academic community; it was essential to its existence (see Volpe, 2008, pp. 9-13; Peiffer and Vittu, 2008, pp. 288-290).

The seventeenth century represented a fundamental moment in the history of Western thought. The forms of learned sociability grew and diversified, and the intellectual life experienced a significant development in new forms and particularly a remarkable fertility.

Rather exceptional events, journeys could not be a usual mode of transmission and dissemination of ideas that circulated most commonly through correspondence. Personal contacts were followed by the establishment of correspondences. Before the introduction of scientific journals, correspondence was the primary vehicle of scientific information, maintaining the life of the Republic of Letters and playing a leading role in the intellectual life of the seventeenth century. Some characters have distinguished themselves in their role as intermediaries. For instance, Father Marin Mersenne played an active role in forging scientific activity by continuing through his correspondence to foster research or elicit comments. Correspondences by such people like Mersenne, Peiresc, Oldenburg or Magliabechi are 
outstanding by their volume, the size of their corresponding networks across Europe, and the invested time and money.

Scientists not only exchanged ideas, principles and demonstrations, but also calculations, observations and experiences. The letter allowed them to express their interests and expose their activities to disseminate news about the progress of their research, and to announce the works published or in preparation to a select audience. Yet, the letter rarely remained confidential; it was released, partly or totally, among the friends of the recipient. The situation changed with the new journals.

With the advent of journals, scientific communication gradually lost its former character of personal exchange. Printed in journals, the letter reached numerous and diverse readers that it could not attain before across Europe. For scientists, periodicals became a vital tool to publish the results of their research and to register and protect the priority of a discovery or an invention. Due to the significant delay of the proceedings of academies, many scholars also submitted preprints of their papers in general journals.

The journal was a forum of expression addressed to the Republic of Letters and beyond, to an interested public taken to witness in controversy and debate. Also, those who could not afford to purchase books could nonetheless learn from the book reviews. Journals met the critical issue of access to scientific information in a time of increasing numbers of authors and printed books. With the development of scientific journals from the last decades of the seventeenth century, the ideal of communication as a powerful engine of the Republic of Letters reached its ultimate form.

Launched in 1665, the Journal des Savants inaugurated a new way of communication in the Republic of Letters (see Vittu, 2002a, p. 180; Volpe, 2008, p. 135; Beaudry, 2011, pp. 124-126). Its success could be measured in terms of its many counterfeits and also by the considerable number of journals launched in the following decades, such as the Giornale de' Letterati (Rome, 1668), Acta Eruditorum (Leipzig, 1682), Histoire des Ouvrages des Savants (Rotterdam, 1687) and the History of the Works of the Learned (London, 1699). This explosion of scholarly journals across Europe is well reported by Pierre Bayle, in his preface to the first edition of its News Republic of Letters in 1684: "It was found so convenient \& pleasant to inform the public through a kind of journal of what was happening in the Republic of Letters, that no sooner had Mr Sallo, Counsellor at the Parliament of Paris, published the first tests of this project at the beginning of the year 1665, than several nations showed their joy, either by translating the Journal he was printing every week, or by publishing something similar. This emulation increased even more from that time, so that it extended not only from one nation to another, but also from one science to another science. The physicists and the chemists have published their special reports; jurisprudence and medicine have their journal; music also has his; gallant news, together with religion, war, \& policy have their Mercure. After all, the initial idea of Mr. Sallo has been executed by almost all in infinite ways."[1]

\section{The "Journal des Savants" v Elzevier case}

The Journal des Savants was counterfeited very early, especially in Amsterdam from 1666 on, only one year after its launch. According to a letter written by Emery Bigot to Nicolas Hensius on March 18, 1665, Daniel Elzevier had instructed his brother to bring him the first issues of the Journal (Vittu, 1988, p. 308) from Paris. This counterfeit was printed until 1680 by the Elzeviers under the name of "Pierre le Grand", then for another two years in Brussels by Fricx, who was in business with Daniel Elzevier until his death in 1680. From 1682 on, the 
Journal was again counterfeited in Amsterdam under the responsibility of the bookseller company Wolfgang, Van Waesberge, Boom and Van Someren. This "Amsterdam printing" was edited in a smaller size, being in duodecimo format rather than in the French quarto. ${ }^{[2]}$

In 1675, the Journal des Savants took a new "impetus" under the direction of a new editor, Jean-Paul de La Roque, a real newspaper man who completely transformed the journal throughout his mandate. The development of direct or indirect correspondence by the Father de la Roque with personalities such as Oldenburg, Grew, Bayle, Huygens, Leibniz, Mencke, Bernoulli, Nicaise, Spon and Magliabechi, as well as the multiple editions of the Journal prove without any doubt the readership of the journal and its establishment in the Republic of Letters.

For the men of science, the Journal des Savants and the related meetings allowed access to the Republic of Letters as much as a vector of dissemination as a kind of "think-tank" for discussion and evaluation. Scholars, amateurs and scientists responded to the expectations of the editor and submitted regular and numerous letters, memoirs and observations. In the late 1670s, the Parisian bookseller replenished his fund by reprinting older issues of the Journal.

The postage cost per issue doubled and limited the shipping opportunities for those who lacked relationships with travellers and traders, a problem that was to facilitate the success of counterfeiting. In Amsterdam, on his own and with no intellectual property rights, Daniel Elzevier resumed his counterfeits both of the current issues and of former editions (Vittu, 2002b, p. 366). In 1684, an observation of Pierre Bayle confirmed the ultimate need of these "fakes": "If in Holland nobody printed the Journal des Savants made in Paris, it would remain forever unknown to all booksellers in the North and in Germany" ${ }^{[3]}$. Bayle's statement was confirmed by a survey of 170 European libraries that most frequently possessed a counterfeit edition, especially in Northern Europe (Vittu, 1988, pp. 301-302 and p. 324). With the production of counterfeits, the journal's distribution centres proliferated. The recurrence of these counterfeits corroborated the success of pirating which spread the journal across Europe. Produced in small annual volumes with different issues, the journal was no longer designed for a readership interested in cutting edge research or the latest scientific curiosities but it now satisfied readers who used it as a catalogue or a book.

The importance of the counterfeits affected the impact and visibility of the Journal des Savants in two ways. On the one hand, they increased its distribution through the creation of a second production centre. Located in Amsterdam, a crossroad of land and sea routes, it sold the journal all around in Northern and Central Europe. On the other hand, they amplified its readership community, less by lowering costs than by switching to a lower frequency that was more interesting for readers who regarded the journal rather as a book, a collection of bibliographic and erudite information. Without its counterfeits, the Journal des Savants would never have achieved such widespread dissemination throughout Europe and such success that, it must be remembered, it also generated a movement in favour of the creation of several other scientific journals.

\section{Counterfeiting in the context - an apology}

The idea of intellectual property appeared only recently in the history of mankind. Previously, writer and artist did not even imagine a literary or artistic conception might be to their benefit, subject to law. The only expected benefits of their work were the honours, awards in competitions, fame and, with it, the chance to be noticed and protected by some Maecenas, jobs and pensions from the government or some great and powerful personality. 
"At the beginning of the book, there is infringement, i.e. both original sin and wonderful chance to the written word" (Moureau, 1988, p. 9). When Gutenberg "counterfeited" the manuscript with typographical lead "imitating" scriptoria practices in incunabula, he invented - with a few others - the art of the printed book, but also, from the commercial point of view, legitimized forgery. Printing is at the origin of copyright but also of counterfeit, fraud and plagiarism.

The idea of copyright began to appear in the fifteenth century with the development of the printing press. Easy copying and distribution of works by printing represented a potential source of material profits. The first traces of this right emerged across the privileges (or licences) of the city of Venice, soon followed by privileges in Italy, Spain, France, Germany and England, the first country to enact a law on copyright in 1709. Under the Ancien Régime copyright was based on a system of monopoly, i.e. a system of privileges granted by the Sovereign, in accordance with the prevailing doctrine that all right comes straight from the public authority. Denys de Sallo and his successors held a royal license for the publication of their journal. Yet, in most cases, the literary monopoly fell into hands (publishers, booksellers) other than those of the author (Ruffini, 1926). Also, under the Ancien Régime, there was no international law and the library police was not very effective. In the absence of any international agreement that would protect copyright, publishers and authors were sometimes tempted to obtain privileges in different countries. In particular, these privileges were often granted by the Pope, the Emperor, the King of France, the King of Spain or the princes. For instance, in 1625 Hugo Grotius published his treatise On the Law of War and Peace in Paris; though Dutch, he had obtained in France a monopoly for a period of fifteen years.

The legal fight against counterfeit and plagiarism was relatively ineffective in the absence of international law applicable to the offense. The privilege granted to a bookseller or author according to the rules under the Ancien Régime was for a fixed term and a well-defined territory. Only books published while the privilege was still operating and on the territory covered by the privilege could be considered as counterfeits. This was the reason why printing a book protected in Paris in Avignon, City of Popes and land of the church, or distributing in Lyon a book whose Paris privilege had expired, was not fraud against law. Also, counterfeiters were often convinced that they were simply exercising a right. For example, in the words of a publisher from Liège to Marmontel of whom he published the Moral Tales without permission: "Your privileges do not extend so far. Liège is a country of franchise, we have the right to print everything that is good, and that is exactly our business."[4]

Usually, the first bookseller to counterfeit a foreign work obtained de facto a sort of monopoly respected by other counterfeiters. Thus, in Holland, forgery was a priority right to the infringer as evidenced by a voluntary agreement (convention), written in Dutch and signed on March 8, 1710 by 54 booksellers: "If anyone were to infringe here any book from a foreign bookseller, the first person who gives notice or shows a printed sheet will be considered the real owner." $"[5]$ This agreement explains the great number of announcements of reprints made by Dutch booksellers in their newspapers. It was in this way that the Elzeviers had granted themselves the monopoly of French counterfeits. Many counterfeiters, in good faith, if not their right, did not hesitate to sign their forgery. When they chose not to do so, it was generally not to escape prosecution but for other, sometimes political reasons.

Finally, although each country at that time possessed its own counterfeiting site for foreign works, the different states took advantage of or, conversely, were affected by fraud in different ways. The most impacted countries could be classified into two categories: on the 
one hand those which, while being of the same nationality and of the same language, had the disadvantage of multiple sovereignties. This is the case of the Netherlands, divided into seven provinces, of Italy, divided into seven states, and of Germany, which had many more. On the other hand, those countries with widely used and expansive language and literature, such as England vis-à-vis America and France vis-à-vis Europe, because of the universal knowledge of the French language and the prevailing liking for French ideas.

Some booksellers unable to distribute their production on their own behalf instigated or created their own "preferred counterfeiters" who disseminated in a decentralized way books in small runs that the publisher could not supply. The case of the major literary journals of the nineteenth century counterfeited in Belgium for the international market clearly shows the continuity of this labour division between an authorized publisher who cannot keep up with demand and a "useful leech" able to meet the needs of the market.

The art of counterfeiting their own works was regular practice of authors like Voltaire for whom the multiplier and explosive effect of counterfeiting was a fundamental element of the propaganda in the Age of Enlightenment (Lumières). In the eighteenth century, the Encyclopedia still witnessed in an eloquent manner to this widespread practice and its interest: "But the main point of view from which we consider a good book is that it provides general instruction to mankind; \& from this point of view, one could never spread fairly quickly or easily enough a book of this nature. Counterfeits are excellent for both goals, first because they are spread in the country where they are forged $\&$ to nearby places; $\&$ because of the price reduction, it is within reach for a very large number people who otherwise might not even have heard of the original edition. Therefore, what right do booksellers say they possess on a book written for the instruction of mankind? How dare they say that it is a property that belongs to them, and that those who counterfeit are pirating? Such remarks betray the love of gain and the ignorance of the human rights."[6]

The argument that copyright was opposed to human rights, or more generally to the progress of mankind, was still put forward in the following century by many of those who continued to contest the recognition of intellectual property. Thus, in 1856, and again in 1866, the Italian politician and activist Giuseppe Mazzini wrote to a publisher in Milan: "I never believed in the law of literary property, as understood today. The author capable of really profitable ideas but without resources, should, in a well-ordered republic, be assisted and encouraged by the nation, yet the expressed thought belongs to all: it is social property. The breath of the human soul cannot be a monopoly. All have a duty to encourage, nobody has the right to impede or restrict the circulation of truth." ${ }^{\text {[7] }}$

\section{Discussion}

Telling old stories may have some distancing or alienation effect. Some familiar topics seem strange at distance. Yet, we should not be misunderstood. This is not a plaidoyer in defence of counterfeit and fraud but an invitation to debate on some specific points.

(1) Life without copyright? The first point is that Denys de Sallo's contemporaries were not aware of anything like copyright protection. And without copyright, no infringement. But we can take this in quite a different way. Living without copyright is possible. That is historical evidence. We can imagine scientific and academic publishing without intellectual property. Or as Rupert Gatti put it: "Eliminating copyright on academic works would (...) enable more efficient and innovative mechanisms" for the delivery of academic publishing (Gatti, 2011, p. 41). At least, it is an interesting option. All those authors and scientists who 
put their works and data in the public domain already chose this option. Habermas described the impact of the invention of the printing technology on the development of concepts like intellectual property, public sphere and privacy (Habermas, 1989). Perhaps, the new technologies of information and communication may contribute to the vanishing of public sphere and copyright protection (Poster, 1995).

(2) Useful piracy? The second point is that even without copyright, there was a problem. Denys de Sallo and his successors held a royal license and never considered their Journal des Savants as a common good; neither did Elzevier. Both were conscious of the fact of the unauthorized use of printed information. Nevertheless, this illegal use contributed, through quick and broader distribution of the "Amsterdam printing", to the success of the journal and to the success of science, too. Does this mean that counterfeiting may contribute to common wealth, that "many kinds of 'piracy' are useful and productive" (Lessig, 2004, p. 66)? This is a statement difficult to accept for authors, professionals and industry, especially those familiar with the continental intellectual property laws, but it is essential for the fair use concept. The everyday struggle with European copyright exceptions for non commercial educational and scientific purposes is directly related to this question.

(3) Meetings needs? Counterfeiting was facilitated if not encouraged and promoted by financial and technical barriers. High prices for printing and distribution, and long distribution processes were obstacles to the normal exploitation of the original product. Thus, counterfeit met a genuine need for scientific information, on the emerging market of early scientific communication. As described above, counterfeiting was not only or at least partly tolerated but also it was sometimes part of a conscious strategy of communication and dissemination. Looking back on more than twenty years with open repositories such as arXiv and HAL provides some concrete material for this question.

(4) Sharing for reuse? The next point is on sharing. The $17^{\text {th }}$ century scholars, amateurs and scientists were concerned with registration but above all interested in debate, controversy and exchange in their open community, the so-called Republic of Letters. Their focus was on knowledge. Translated in modern terminology, they wanted recognition of authorship but set no other conditions for reuse. One can suppose that in our time, the Journal des Savants, unlike most modern scientific journals, would have been published under Creative Commons, with a CC-BY licence only requiring attribution to the original author. Also, for a Journal des Savants published under CC-BY, counterfeiting, reprinting and reselling would not have been a real legal problem. The ongoing discussion on the best licence for reuse of data and papers (or no licence at all), on gratis or libre open access (see Suber, 2012, pp. 65-75) is just another illustration of this point.

(5) Work integrity? In the $17^{\text {th }}$ century, content was unstable, science was looked upon with distrust, and counterfeiting contributed to this problem because the different versions could be (were) different without guarantee of the original work's integrity. This problem subsists, with different versions of academic publications being disseminated through different communication channels, but may be better controlled due to metadata and unique identifiers. Yet, the problem is still there, with preprint, postprint and publisher's versions, on validated and on validated theses and dissertations, non peer reviewed working papers etc. being sometimes a kind of professional nightmare for librarians and scientists.

(6) Business? Law? Alternatives? Since de Sallo's century, printing houses and publishers changed their mind on copyright and counterfeits. Yet, their function and purpose remain more or less unchanged: meet the need of the scientific community for quick, 
widespread and selective communication of research results through customized and addedvalue products and services, and get money out of this business. The legal context changed, the business didn't, neither for the publishing industry nor for the Republic of Letters, i.e. the scientific community that is above all interested in recognition, debate, and sharing (see Mulligan and Mabe, 2011, p. 309). This means also, that to the extent that the mediation becomes an obstacle for open, smooth and seamless distribution of information, for instance through high pricing or excessive protection, the Republic of Letters will search for alternative options, such as direct communication. In fact, they have already started to adopt them.

\section{Conclusion}

Our paper started with the question as to whether copyright stimulates artistic and scientific creation or whether, on the contrary, copyright protection reduces dissemination of information and culture. Does a weak copyright system promote technological innovation and economic growth, as Höffner (2010) appears to suggest?

Historical evidence is ambiguous and unethical. What is good today may be bad tomorrow. Often, interests, needs and business are more important than values, ethics and law. Obviously, rights infringement cannot only promote the interest and objective of the rights holder but above all, it can contribute to the emergence and development of new forms of scientific life. "Every generation welcomes the pirates from the last" (Lessig, 2004, p.66). On the other hand, the context has changed and the players - scientific community (Republic of Letters) and publishers - switched their roles. Yet, to quote Georges Santayana, "Those who cannot remember the past are condemned to repeat it."

Today, in the post-Gutenberg galaxy, it appears that "copyright in the new medium will be difficult to protect" (Oppenheim, 2000, p. 295). Today, copyright battles oppose Samsung and Apple, publishers and academic libraries, and the tragic and sad hero of piracy is Aaron Swartz. Will law be the solution? Nothing is less certain. This case study tells a different story. Sometimes, when barriers to communication and debate are too strong, tolerated and calculated infringement may be an option to move the lines.

This paper tells a story that is more than 300 years old. No doubt, other stories could be told, with other morals. Maybe there is no moral at all. Lessons of history lie in the eyes of the beholder. Our own story is being written right before our eyes. It is made up of open access, common goods and public domain, open data and e-Science, evaluation, innovation, sustainability, communication and sharing. We must make up our own mind to it, based on our own experiences, convictions and ethics. But we should be aware that even if our answer must adapt to the actual context, the underlying questions have been raised long time ago. Science is not private but social property. "Nobody has the right to (...) restrict the circulation of truth" (Mazzini, loc.cit., p. 244). And let us add: nobody can, anyway.

\section{Bibliography}

Beaudry, G. (2011), La communication scientifique et le numérique, Lavoisier Hermès Science Publications, Paris.

Cook, A. (2001), “Academic Publications before 1940”, in Fredriksson, E. H., A century of science publishing, IOS Press, Amsterdam, pp. 15-24. http://ebooks.iospress.nl/Download/Pdf/29498 (accessed 9 July 2013). 
Crews, K. D. and van Westrienen, G. (2007), "Copyright, Publishing, and Scholarship”, DLib Magazine, Vol. 13 No. 1/2. doi:10.1045/january2007-crews

Dobusch, L. (2011), “The digital public domain: relevance and regulation", in 1st Berlin Symposium on Internet and Society, October 26th - 28th, 2011. http://www.dobusch.net/pub/uni/Dobusch\%282011\%29The_Digital_Public_Domain-

Relevance_and_Regulation.pdf (accessed 26 August 2013). Also published as Dobusch, L. (2012), "The digital public domain: relevance and regulation", Information \& Communications Technology Law, Vol. 21, No. 2, pp. 179-202. doi:10.1080/13600834.2012.711619

Gaster, J., Schweighofer, E. and Sint, P. (Eds.) (2008), Knowledge Rights. Legal, societal and related technological aspects. KnowRight 2008. Conference Proceedings. September 1819, 2008, Krakow, Poland, Österreichische Computer Gesellschaft, Wien. http://irisj.eu/inhalte/knowright08.pdf (accessed 9 July 2013).

Gatti, R. (2011), "CAM Debate: Access all areas", CAM Cambridge Alumni Magazine, Vol. 62, pp. 40-41. http://www.alumni.cam.ac.uk/news/cam/cam62/ (accessed 9 July 2013).

Georgiades, E. (2010), "Copyright liability for users and distributors of content sharing and communication technologies: a crossroads between past and present", Information \& Communications Technology Law, Vol. 19 No. 1, pp. 1-26. doi:10.1080/13600831003593154

Guédon, J.-C. (2001), In Oldenburg's long shadow: librarians, research scientists, publishers, and the control of scientific publishing, Association of Research Libraries, Washington, DC.

Habermas, J. (1989), The structural transformation of the public sphere: an inquiry into a category of bourgeois society, MIT Press, Cambridge, Mass.

Höffner, E. (2010), Geschichte und Wesen des Urheberrechts, Verlag Europäische Wirtschaft, München.

Lessig, L. (2004), Free culture: how big media uses technology and the law to lock down culture and control creativity, Penguin Press, New York.

Mabe, M.A. (2009), "Scholarly Publishing”, European Review, Vol. 17 No. 01, pp. 3-22. doi:10.1080/13600831003593154

Mulligan, A. and Mabe, M. (2011), "The effect of the internet on researcher motivations, behaviour and attitudes", Journal of Documentation, Vol. 67 No. 2, pp. 290-311. doi:10.1108/00220411111109485

Moureau, F. (1988), “Avant propos », in Moureau, F., Les presses grises : la contrefaçon du livre (XVIe-XIXe siècles), Aux Amateurs du Livre, Paris, p. 9.

Oppenheim, C. (2000), "Does copyright have any future on the internet?", Journal of Documentation, Vol. 56 No. 3, pp. 279-298. doi:10.1108/eum0000000007116

Peiffer, J. and Vittu, J.-P. (2008), "Les journaux savants, formes de la communication et agents de la construction des savoirs (17e-18e siècles)", Dix-huitième siècle, Vol. 40 No. 1, pp. 281-300. doi:10.3917/dhs.040.0281 
Posner, R.A. (2012), "Do patent and copyright law restrict competition and creativity excessively?", in The Becker-Posner-Blog, 9/30/2012. http://www.becker-posnerblog.com/2012/09/do-patent-and-copyright-law-restrict-competition-and-creativityexcessively-posner.html (accessed 26 August 2013).

Poster, M. (1995), "Cyberdemocracy: Internet and the public sphere", in Porter, D., Internet Culture, Routledge, New York, pp. 201-217. http://www.hnet.uci.edu/mposter/writings/democ.html (accessed 26 August 2013).

Potts, C.H. (2011), "Journal des Savants", Journal of Scholarly Publishing, Vol. 43 No. 1, pp. 68-75. doi:10.3138/jsp.43.1.68

Roosendaal, H. E., Zalewska-Kurek, K., Geurts, P. A. Th. M. and Hilf, E. R. (2010), Scientific Publishing: From Vanity to Strategy, Chandos Publishing, Oxford.

Ruffini, F. (1926), "De la protection internationale des droits sur les œuvres littéraires et artistiques", Recueil des Cours de l'Académie de Droit International, Vol. 12, pp. 387-597.

Suber, P. (2012), Open access, MIT Press, Cambridge Mass. http://mitpress.mit.edu/books/open-access (accessed 9 July 2013).

Vittu, J.-P. (1988), "Les contrefaçons du Journal des savants de 1665 à 1714", in Moureau, F., Les presses grises : la contrefaçon du livre (XVIe-XIXe siècles), Aux Amateurs du Livre, Paris, pp. 303-331.

Vittu, J.-P. (2002a), "La formation d'une institution scientifique : le Journal des Savants de 1665 à 1714 (1)”, Journal des savants, No. 1, pp. 179-203. doi:10.3406/jds.2002.1653

Vittu, J.-P. (2002b), "La formation d'une institution scientifique : le Journal des Savants de 1665 à 1714 (2)”, Journal des savants, No. 2, pp. 349-377. doi:10.3406/jds.2002.1659

Volpe, T. (2008), Science et théologie dans les débats savants de la seconde moitié du XVIIe siècle: La Genèse dans les Philosophical Transactions et le Journal des savants (16651710), Brepols, Turnhout.

Voyles, B. (2013), "Promoting innovation in society", in CKGSB Knowledge Blog, 5/8/2013. http://knowledge.ckgsb.edu.cn/2013/05/08/intellectual-property/promotinginnovation-in-society/ (accessed 26 August 2013).

Weil, F. (1988), “Contrefaçon et droit de copie avant 1777”, in Moureau, F., Les presses grises : la contrefaçon du livre (XVIe-XIXe siècles), Aux Amateurs du Livre, Paris, pp. 87100.

For further reading:

Armstrong, E. (1990), Before copyright: the French book-privilege system, 1498-1526, Cambridge University Press, Cambridge.

Biagioli, M. (2011), "Genius against Copyright: Revisiting Fichte's Proof of the Illegality of Reprinting", Notre Dame Law Review, Vol. 86 No. 5, pp. 1847-1867. 
Darnton, R. (1979), The business of enlightenment. A publishing history of the Encyclopédie, 1775-1800, Harvard University Press, Cambridge, MA.

Hugenholtz, B.P. (2000), "Copyright vs. freedom of scientific communication", Learned Publishing, Vol. 13 No. 2, pp. 77-81.

Johns, A. (2011), Piracy: the intellectual property wars from Gutenberg to Gates, University of Chicago Press, Chicago, ILL.

Long, P.O. (2001), Openness, secrecy, authorship: technical arts and the culture of knowledge from antiquity to the Renaissance, Johns Hopkins University Press, Baltimore, MD.

Mueller-Langer, F. and Scheufen, M. (2013), "Academic Publishing and Open Access", in Handke, C. and Towse, R. (Eds), Handbook of the Digital Creative Economy, Edward Elgar, Cheltenham.

Shavell, S. (2010), "Should Copyright of Academic Works be Abolished?", Journal of Legal Analysis, Vol. 2 No. 1, pp. 301-358.

Stallman, R. (2001), "Science must 'push copyright aside", Nature webdebates - Future eaccess to the primary literature (online), 8 June 2001, available at: http://www.nature.com/nature/debates/e-access/index.html (accessed 12 March 2013).

Vittu, J.-P. (1997). Le Journal des savants et la République des Lettres, 1665-1714. Ph.D. thesis, Université Panthéon-Sorbonne (Paris).

\footnotetext{
${ }^{[1]}$ In French: «On a trouvé si commode \& si agréable le dessein de faire sçavoir au Public, par une espèce de Journal, ce qui se passe de curieux dans la République des Lettres, qu'aussi-tôt que Monsieur Sallo, Conseiller au Parlement de Paris, eut fait paroître les premiers essais de ce Projet au commencement de l'année 1665, plusieurs Nations en témoignèrent leur joye, soit en traduisant le Journal qu'il faisoit imprimer tous les huit jours, soit en publiant quelque chose de semblable. Cette émulation s'est augmentée de plus en plus depuis ce temps-là ; de sorte qu'elle s'est étendue non seulement d'une Nation à une autre, mais aussi d'une science à une autre science. Les Physiciens, \& les Chymistes ont publié leurs Relations particulières ; la Jurisprudence, \& la Médecine ont eu leur Journal ; la Musique aussi a eu le sien; les Nouvelles Galantes diversifiées par celles de Religion, de Guerre, \& de Politique ont eu leur Mercure. Enfin on a vu le premier dessein de Monsieur Sallo executé presque par tout en une infinité de manières». In Pierre Bayle, Nouvelles de la République des Lettres. Preface. March 1684. $2^{\text {nd }}$ revised and corrected edition, Henry Desbordes, Amsterdam 1684. Non paginated in original edition. In the 1966 reprint (published by Slatkine, Geneva) pp. 7-10.

${ }^{[2]}$ A large set of the Amsterdam printing (220 vol. from 1665 to 1759) was acquired by the Dibner Library of the History of Science and Technology (Smithsonian Institution Libraries, Washington, D.C.) in 2000.

${ }^{[3]}$ In French: «Si l'on n'imprimoit pas en Hollande le Journal des Sçavans, qu'on fait à Paris, il demeureroit inconnu pour toujours à tous les libraires du Nort, \& de l'Allemagne.» In Pierre Bayle (loc.cit., non paginated, p. 10 in reprint).

${ }^{[4]}$ In French: «Vos privilèges ne s'étendent point jusqu'ici: Liège est un pays de franchise. Nous avons donc droit d'imprimer tout ce qu'il y a de bon; c'est là notre commerce.» In E. Laboulaye and G. Guiffrey, La propriété littéraire au XVIIIe siècle, Paris, Hachette, 1859, p. III, note 2.

${ }^{[5]}$ In French: «Si quelqu'un venait à contrefaire ici quelque livre d'un libraire étranger, celui qui le premier en donnera avis ou montrera une feuille imprimée sera réputé pour le véritable possesseur.» See also Weil (1988). ${ }^{[6]}$ In French: «Mais le principal point de vue sous lequel nous devons envisager un bon livre, c'est l'instruction générale qu'il procure à l'humanité ; \& sous ce point de vue, on ne sauroit jamais répandre assez rapidement, ni assez facilement un livre de cette nature. Les contrefaçons sont excellentes pour obtenir ces deux buts, parce qu'on les répand d'abord dans le pays où on les contrefait \& aux endroits voisins; \& par la diminution du prix, on met à portée de l'acheter un très grand nombre de personnes, qui peut-être n'auroient pas seulement oü̈ parler de l'édition originale. Or quel droit les libraires prétendent-ils avoir sur un livre destiné à l'instruction
} 
des hommes? Comment osent-ils dire que c'est un bien qui leur appartient, que le métier de ceux qui contrefont, est une piraterie? Des propos pareils décelent la passion du gain \& l'ignorance des droits des hommes.» In Encyclopédie ou Dictionnaire universel raisonné [...], arranged by M. De Félice, Yverdon, t. XI, 1772, p. 265. ${ }^{[7]}$ In G. Mazzini, Scritti editi ed ineditti, vol. IX, Roma, 1877, p. 244. 